Journal of Social and Development Sciences

Vol. 6, No. 1, pp. 24-31, March 2015 (ISSN 2221-1152)

\title{
Structuring Models and Characteristics of Informal Sector Traders in Indonesia (Case Study in Informal Sector Jakarta City, Indonesia)
}

\author{
*Sri Hartati, Rukmi Juwita, Edwin Karim, Kartib Bayu \\ School of Business and Management Institute Technology Bandung (ITB), Indonesia \\ *sri.hartati@sbm-itb.ac.id
}

\begin{abstract}
Socio-economic aspects that occur in urban communities to create activities that are formal and informal that is the dualistic nature of the urban. Formal activities often associated with activities performed by the people in the middle class and above, while the informal nature of activities carried out by community group lower middle class or the marginalized. Urban dualistic also featured in the historical evolution of the modern sector and the traditional sector is dualistic technology. The problems posed by urban dualistic phenomena are often caused by the immaturity of the planning and supervision of construction in all parts of the city where this dualistic condition often develops itself spontaneously, unplanned and illegal. One of the problems arising in connection with the dualistic model of the labor market in the urban informal sector and the use of the term formal sector, street vendors (PKL) is likely to be the type of work that is important and relatively typical in the informal sector. Indonesia experienced economic downturn or economic crisis in 1998 the economic crisis resulted in good economic burden of community, government and private sector so that the towering including private cause limiting the number of employees with layoffs (layoffs). The economic burden society spiraling out of control resulting in the community looking for their own jobs in the informal sector to select, because the government is not able to overcome it with the community to accommodate retrenched workers in the formal sector. Choices made by the society be one with the informal traders as assessed requires little capital and skills. Unwillingness of society in a state of uncertainty, political stability is shaky, the goods of daily needs such as food prices soar resulting purchasing power declined, unemployment increased while time goes on and needs to be bought, then open their own jobs by becoming a trader informal community considered as an appropriate solution, although not necessarily in sales turnover and relatively small, but it can ease the burden of life. Methods Comparative research is a descriptive study. Choices made by the society be one with the informal traders as assessed requires little capital and skills. Unwillingness of society in a state of uncertainty, political stability is shaky, the goods of daily needs such as food prices soar resulting purchasing power declined,increased unemployment while time goes on and needs to be bought, then open review their own jobs by becoming a trader considered as an informal community solution, although not necessarily in sales turnover and relatively small, but it can ease the burden of life. Methods comparative research is a descriptive study. The results showed the characteristics of informal sector traders largely based on the age-old 15-54 years. The level of education pursued most primary and secondary school graduates. Background informal traders most of Informal Traders Become reason.business activities, ranging from early-afternoon (9:00 to 16:00), afternoon-evening (16.00-00,00) and all day (24 hours). Most informal traders do not have the permission to conduct business. The amount of capital 1 - 5 million dollars. Capital sources used are mostly using their own capital.
\end{abstract}

Keywords: Model,characteristic, informal sector,unemployment and trade

\section{Introduction}

Socio-economic aspects that occur in urban communities to create activities that are formal and informal by nature is dualistic in urban areas. Formal activities often associated with activities performed by the people in the middle classes and above, while the informal nature of activities carried out by community groups to lower middle class or the marginalized. Urban dualistic also featured in the historical evolution of the modern sector and the traditional sector is dualistic technology.The problems posed by urban dualistic phenomena are often caused by the immaturity of the planning and monitoring of development in all parts of the city where this dualistic condition often develops itself spontaneously, unplanned and illegal. One of the issues arising in relation to the dualistic model of the labor market in the urban informal sector and the use of the term formal sector, traders is likely to be the kind of work that is important and relatively unique in the informal sector. (Yustika, 2003: 230). On the other hand, it 
is undeniable that the informal sector is not necessarily cause problems in urban activities, but there is a positive side in the informal sector. The informal sector can be regarded as the savior of the belt that holds the excess labor that can not be accommodated in the formal sector. Indonesia experienced the economic downturn or economic crisis that occurred in 1998. The economic crisis has resulted in good economic burden society, government and private sector so that such towering cause limit the number of private employees by conducting layoffs. The economic burden society increasingly uncontrollable result of the community's own search for employment in the informal sector to select, because the government is not able to overcome this by accommodating the victims of layoffs in the formal sector.

Choice made by the society be one with the informal traders as assessed requires little capital and skills. Unwillingness of society in a state of uncertainty, a shaky political stability, items of daily necessities such as food prices soar resulting decreased purchasing power, unemployment is rising while the time goes and needs to be bought, then opened his own jobs by becoming a trader informal communities regarded as the right solution though not necessarily in sales turnover and relatively small, but it can ease the burden of life. The role of informal traders is very strategic city as a safety valve unemployment. In many major cities, when the crisis hit Indonesia and unemployment occur everywhere, the only opportunity that could save millions of victims survival layoffs and unemployment are the informal sector. Informal Sector in Indonesia is able to absorb about 70 percent of the workforce, and the rest in the formal sector. One cause of the size of the informal sector in Indonesia is unskilled labor. Unskilled labor dilator low levels of educational background and expertise of the workforce, so it is not qualified to work in the formal sector. This can be attributed to the magnitude of unemployment, so that workers who are unable to work in the formal sector, are forced to work in the informal sector, in order to survive.

Nevertheless, the existence of informal traders in urban areas is often problematic. Problems informal traders is an issue that always happens in every city. As in Depok, its existence on the one hand is one of the engines driving the economy of the city, but on the other hand the problem is very complex and complicated handling. The existence of a burgeoning informal traders and the lack of awareness for arranging his wares can not only lead to a conflict of interest, traffic congestion and chaos, but also the comfort, cleanliness and safety of other road users.Effort to organize informal traders need to be done to reduce the negative impacts and enhance its positive contribution. Handling informal traders should be placed as the subject of dignity, through dialogue approaches and activities that are not only repressive, because its existence is one of the engines driving the economy of the city, so it can be styled properly.The existence of informal sector traders in Depok city, especially around Jalan Siliwangi, Tole Jalan Iskandar and Jalan Juanda, which is done by opening the stall or vend in a stroller, often causing congestion and sights that are not good and often cause damage to the environment with garbage. Five Feet merchants as one of the activities of the informal sector is also often interfere with pedestrians as cover roads that should be used by pedestrians.

Let alone the informal sector is also not a good decision, because the sector can also be very inefficient and could compromise the security of the environment. Therefore it is anticipated that the negative impacts and maximize positive impacts. One that can be implemented is to organize informal traders without having to make it directly into a formal.Government policies and programs have been carried out for the arrangement of informal traders in Depok. However, this arrangement during the informal traders had not been optimal and significantly impact has not been felt. The parties concerned with the arrangement of informal traders often walk with their own goal and often does not occur synergy. In addition, the arrangement of informal traders who are already running for this tend to be oriented to the "policing" the sheer lack of attention to the interests of informal traders community so the results do not continue and often conflicting.Governments and other stakeholders need to undertake concrete steps to empower businesses pentaan and informal traders. All interested parties need to work together in synergy (a partnership) to devise ways of structuring and empowerment of informal traders who can be accepted by all parties, both by the government, the community, and the community's own informal traders. If the informal traders directed and nurtured and empowered, the impact on the national economy and the very large area. Based on the above phenomenon, the arrangement pendataanndan informal traders in Depok Kopta be urgently implemented. It is hoped that the data collection and arrangement of appropriate informal traders will be able to create an atmosphere of Depok City clean, beautiful, neat, and comfortable supported by an increase in income and welfare of the informal traders who in turn can help in the effort to create jobs and improve the original income 


\section{Literatur Review}

The development of dualistic concepts that occur in particular in developing countries experience the dynamics that often cause problems in these countries especially in urban areas. Dualistic concept was first introduced by a Dutch economist, Boeke which is the research findings on the causes of the failure of wisdom (economics) the Dutch in Indonesia (Lincolyn and Egon, 1985: 208), put forward his theory of social dualism in developing countries and that sense defines as a contradiction of a system that is imported by indigenous social system, who has a different hue. As an alternative to the social dualism (Boeke,1978) duality theory building technology found that the origin of dualism is the technological differences between the modern sector and the traditional sector, or in other words a situation where in an economic activity used certain production techniques and modern production organization that is very different from other economic activity and would ultimately lead to differences in the level of productivity is very large. Various shades of barriers arising from the presence of the dualistic nature of the economy that occurred in developing countries also hit cities in Indonesia. This is evidenced by the results of the research findings Boeke who took Indonesia as the region of study. The emergence of the dualistic nature of the problems give the phenomenon due to different aspects of city life espek. In urban areas, the dualistic nature displayed by many things, including be seen from the formal and informal sector, rich and poor, natural and artificial, physical and non-physical as well as traditional and modern as expressed in social dualism Boeke ( Lincoln and Egon,1985).

Definition and Characteristics of the Formal Sector: According to Manning and Tadjudin (1996: 111), the activity is called formal or not, that sets it apart is the bureaucracy in the field of licensing. Tend to be more formal business protected from the informal group. The protection afforded by the organization of the government or labor organizations. The formal sector according to Hart ( Manning and Tadjuddin, 1996: 211) is divided into three parts, namely:

- The private business sector with five or more workers.

- The government sector.

- The organized private sector which employs less than five people.

Manning and Tadjudin (1996: 211) also explains that in formal activities, also known quasi-term formal sector which includes: professional workers own business (lawyers, doctors, entrepreneurs), domestic industrial activity, small business units with machines, construction workers and commercial activities with large capital. This quasi-formal sector is that certain activities should not require high skills or major capital but can generate income is high because of factors kestrategisan located in the city. Against the opportunity to earn between formal and informal sectors. Manning explained basically lies in the difference between earned income and income from their own business. (Manning and Tadjudin, 1996: 78).

Concept of Informal Sector: The concept of urban informality can not be separated from the dichotomy of the formal sector and the informal sector was the buzzword in the early 1970s. The phenomenon of the informal sector is a very common phenomenon in developing countries. Describes that the informal sector as part of the labor force in a city that is outside the labor market is not organized. Looking at the reality of course, the existence of the informal sector is very important in reviving economic activity in a country, especially in third world countries (Manning, 2000: 189). Through his book Urban Informality: Transnational Perspectives from the Middle East, Latin America and South Asia, introduced the concept of urban informality as a logic that explains the process of urban transformation. In this case, do not emphasize the dichotomy of the formal and informal sector, but on the understanding that no informality as a separate sector in the economic structure of society. According to them, this informality is a mode of urbanization that connects the various economic activities and living in urban areas.

The realm of economics explicitly distinguished between the informal sector with the informal economy (Yustika,2000). For the context of the informal economy, there are at least four production sectors where the informal sector is one of its parts. The informal sector is characterized as a small-scale producers, using their own labor for the production of goods as well as many involved in business activities, transport and service provision. Usually the output of the informal sector is sold as goods and services between (intermediate goods and services) to other manufacturers or as final goods (final demand) directly for consumption and thus already contained in the informal sector market. The most important thing to note, that all goods and services produced in the informal sector are legal, although in 
general there are no rules in the process of production and distribution. Studies conducted (Yustika, 2000) on the informal sector in the context of Indonesia produced characteristics of informal sector activities include irregular pattern, both in terms of time, capital and acceptance, not touched by the rules or regulations set by the government, capital equipment and supplies as well as the turnover is usually small and arranged on the basis of the daily count. Generally do not have any other big businesses, generally done by and serve the low-income segments of society, does not require special expertise and skills, each unit generally employ a little effort and environmental relationships of family, acquaintances or from areas same, and do not know the banking system, bookkeeping, credit and so forth

Relationship Informal Sector and Formal Sector: Urban dualistic condition occurs with the development of an urban area. Dualistic condition can be seen from the emergence of the term formal sector and the informal sector. The formal sector includes companies that have a legal status, recognition and official permission, and generally beskala great. While the informal sector business activities generally simple, does not have a business license, generally low income levels, linkages with other businesses are very small, diversified its business, and the business scale is relatively small (Simanjuntak and Wantonius, 2004). According to Ramli (1992) that the informal sector as a provider other than field of job also where the informal sector is the ability to survive in the urban without driven of government is because of the need for a wide range of products and services produced by the informal sector ini.Any assumed that the informal sector formal need condition so exactly right to say that the formal sector and informal like related and complementary in urban economic activities. One form of informal sector trade is so important is the street vendors. Even so important and since has in the informal sector, informal term always identificated with the type of work performed by vendors. On the other hand the activities of street vendors turned out to give a big contribution in economic activity and well-being of people, especially in economically weak. In addition, the activities of the informal sector is a characteristic that is independent of people's economy and concerns the lives of many people. Consider the potential condition and proper handling practices and training activities of street vendors should be based on the concept of environmentally friendly behavior and characteristics in order to fill in the appropriate settings. Most of the street vendors and the surrounding urban region are not natives (immigrants from outside the village or province), and is not a first choice as a livelihood.

\section{Methodology}

Based on the objectives to be achieved, this type of study is a comparative descriptive study (comparatif descriptive research), which is done by conducting a survey.Survey research is descriptive research method is a method of research to create a picture of an event. Method survey conducted when the data sought is already there in the field or object of research has been clear. The data used consist of primary data and secondary data, both qualitative and quantitative. The unit of analysis in this study is on informal traders in Depok. Determining the location of the samples was done intentionally (purposive), whereas the determination of the unit of analysis done by census to the entire population of the informal trades. Data were analyzed based on the dimensions of time and space is a collection of data a certain time (cross-sectional).

\section{Result}

Characteristics Informal Traders: Based on the primary data collected as many as 199 people Traders infromal time consisting of five 58 informal traders road section Tole Iskandar, 67 informal traders in Jalan Juanda and 74 informal traders in Jalan Sentosa Depok city, it is known characteristics of the informal traders in the city of Depok. Characteristics traders like age, level of formal and informal education, gender, family responsibility and the type of business

Activity oF Informal Traders: A description of the business activities of the informal sector is very important in the know, in an effort to make the arrangement and empowerment of informal traders. Based on activities undertaken by informal traders, it will be able to determine the model of the arrangement and empowerment will be undertaken. The business activities of traders seen e previous efforts, the reason to trade, trade sites, live right now, the source address, the number of family who trade, living conditions, status, type of goods sold, to pay the levy, do cooperation.number of labor, capital businesses, capital resources and income of informal sector traders 
Arrangement of Informal Traders: Under real conditions have been outlined in Chapter $\mathrm{V}$ of the Informal Traders profile in Depok, subsequently in informal sector traders need this arrangement. As a legal basis in the informal sector traders arrangement is the Minister of Home Affairs of the Republic of Indonesia Number 41 of 2012 on Guidelines structuring and empowering vendors. Which is taken into consideration the importance of the arrangement of street vendors are:

a. That the increase in the number of street vendors in the area have resulted in the disruption of smooth traffic, aesthetics and hygiene as well as the function of the urban infrastructure necessary arrangement of street vendors;

b. That the activities of hawkers as one populist economic enterprises engaged in the informal sector trading business empowerment needs to be done to improve and expand its business;

Central Government, provincial and city district government has the authority to provide guidance in structuring and empowerment of street vendors. In accordance with the Regulation of the Minister of the Interior of the Republic of Indonesia No. 41 of 2012, I Article 2 states that:

(1) The Minister is authorized to provide guidance in structuring and empowerment of traders.

(2)The Governor and Regent/Mayor shall make arrangement and empowerment of trades.

And than in Article 3 says that the guidance in structuring and empowerment include:

a. Data collection;

b. Planning the provision of space for informal sector activities;

c. Facilitating access to capital;

d. Institutional strengthening;

e. Coaching and technical assistance;

f. Facilitation of inter-regional cooperation; and

g. Develop partnerships with the business world.

Each level of government have power and duties of each relevant level. In Article 7, the Governor did the arrangement of traders through:

a. Facilitation arrangement of street vendors across districts / cities in the region;

b. Facilitate cooperation between the arrangement of traders districts / cities in the region; and

c. Coaching regent / Mayor in the region.

While on Article 8 Regent / Mayor make arrangement of traders by:

a. Documentition

b.Registration

c. Determination of the location of street vendors

d. Removal of street vendors and the elimination of the location of traders

e. Rejuvenation of the location of traders.

Data Collection: In Article 9, paragraph 2, states that traders stages in conducting data collection as described in paragraph (1) shall be carried along by way of village officials, among others:

a. Make a schedule of implementation of data collection;

b. Mapping the location; and

c. Validating / updating data.

Registration: The next step in making the arrangement is to register traders. In Article 18 states that: (1)The regent / Mayor in charge of affairs on education through traders registration. (2)The registration is done by traders on education affairs in charge of traders along with groove.

(3)Registration of vendors for the control of traders and ensure legal certainty sought.

Location Determination: Determination of the location for street vendors is very important, because one of the causes of frequent occurrence in the handling conflict is an error in the determination of the location. Article 33 states that:

(1) The Regent / mayor set to the given location or region as the location of the business premises of street vendors.

(2) Determination of the location or region is done by taking into account the public interest, social, cultural, aesthetic, economic, security, order, health, hygiene and environment in accordance with the Local rules of the Provincial Spatial Plan and Regency / City.

(3) Where is the location of the target set by goverment. 
(4) The location of the target that has been set is equipped with a nameplate and the location of signs or marks that describe the restrictions on the number of street vendors in accordance with the legislation.

The Move, Elimination and Rejuvenation Location: Displacement and Elimination Location traders described in Article 36 which states that:

(1) Traders who occupy the location is not appropriate designation to do the removal or relocation of traders to place / space designation.

(2) Elimination of the location where the attempted street vendors have been moved to be disciplined and organized in accordance with the intended function.

(3) Change the location of street vendors and street vendors set olehBupati deletion / Mayor.

Development Of Informal traders: Community Informal traders (vendors) in Depok is a marginal community groups need to be empowered in order to be able to do so as the level of economic activity throughout their life-enhancing and further contribute to regional development in particular and the nation in general. This group generally have limitations to doing business, among others: (1) lack of capital, (2) low level of education, and (3) Lack of access to government policy, information and means of economic and social. Attempts to overcome these weaknesses need to be done so that these communities become more empowered in doing business. Effort to organize traders should be made to reduce the negative impacts and enhance its positive contribution. Handling vendors should be placed as the subject of dignity, through dialogue approaches and activities that are not only repressive, because its existence is one of the engines driving the economy of the city, so it can be styled properly. To determine the pattern of development of traders factors considered as follows:

- Aspects of Entrepreneurs (Performance)

a. Commitments include: Motivation (Economic, Social, and Psychological Discipline), Learning (learning process), and Eksperience (experience);

b. Competencies include: Technical Skills, Management Skills, Eksperience (Development).

- Aspects of Business (Commodity)

a. Market attractiveness: Potential customers, suppliers, competitors, changes, and policy.

b. Resources: raw materials, human resources (labor), capital, technology, and institutional (organization).

Figure 1: Model of Empowerment Traders

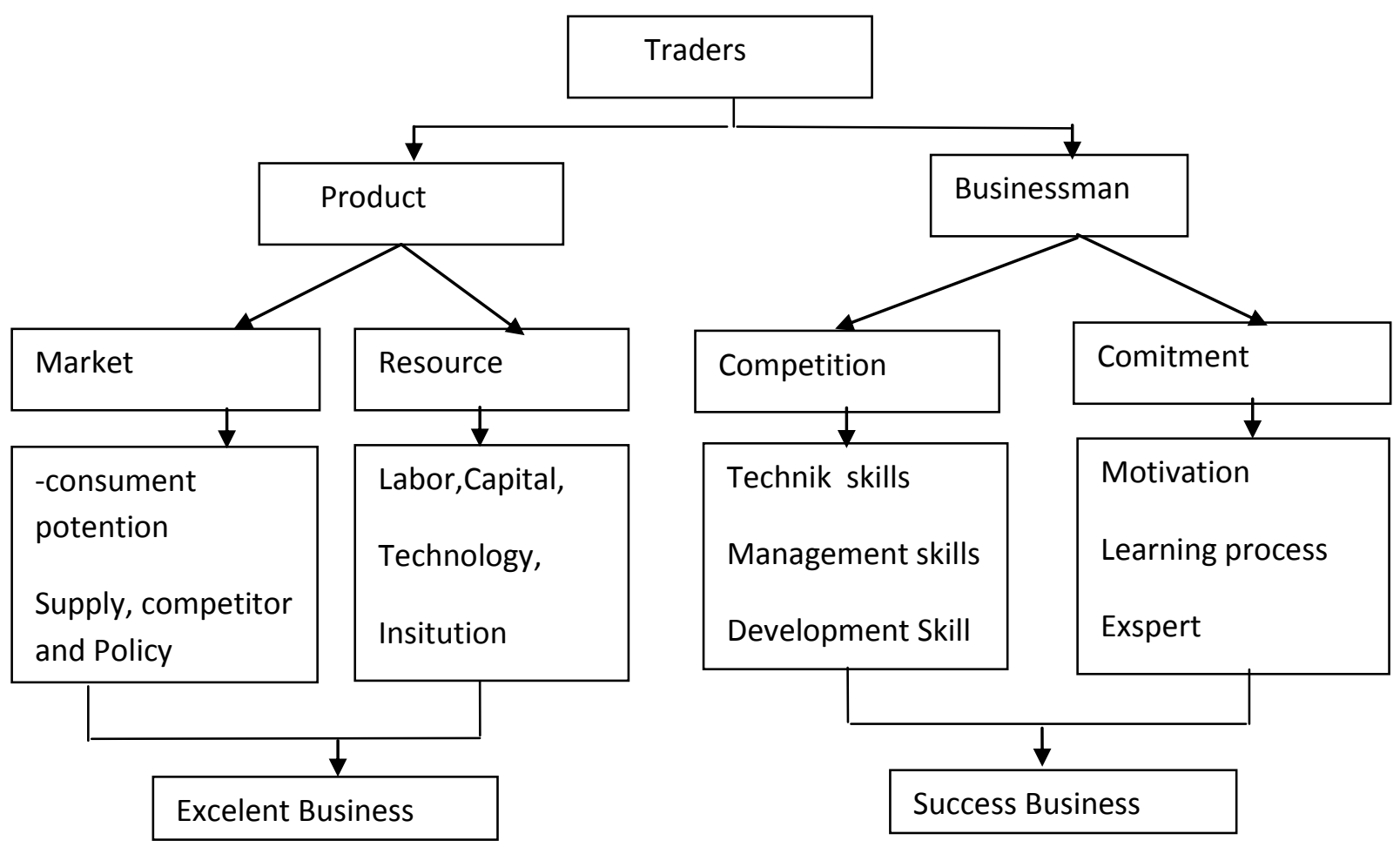




\section{Conclusion and Recommendation}

- Based on the primary data collected as many as 199 traders informal time consisting of five 58 informal traders road section Tole Iskandar, 67 informal traders in Jalan Juanda and 74 informal traders in Jalan Sentosa Depok city, it is known characteristics of the informal traders in the city of Depok. Characteristics traders like age, level of formal and informal education, gender, family responsibility and the type of business

- A description of the business activities of the informal sector is very important in the know, in an effort to make the arrangement and empowerment of informal traders. Based on activities undertaken by informal traders, it will be able to determine the model of the arrangement and empowerment will be undertaken. The business activities of traders seen ari previous efforts, the reason to trade, trade sites, live right now, the source address, the number of families who trade, living conditions, status, type of goods sold, to pay the levy, do cooperation,number ofah labor, capital businesses, capital resources and income of informal sector traders

- Need for identification informal traders and data collection informal sector traders registration structuring business location ,the transfer, elimination and Rejuvenation Location

- Some things that need to be done to empower the informal sector traders are:

$>$ Strengthening the capacity of the business or entrepreneurial development among traders either through training or capacity building for traders,

$>$ The need to support economic empowerment through access to capital,

$>$ The need to establish closer communication with bureaucrats,

$>$ The need to establish a joint forum between the stake holders in the development of street vendors that have competitiveness in the modern market,

$>$ Need assistance to traders in solving problems associated with the constraints faced by traders,

$>$ Planning with environmental ducation to prevent untidiness and behavior favorable to the development of the location of traders,

$>$ Need Strengthening Communities positioning vendors in establishing bargaining with other parties,

$>$ Should be considered as an attempt to position vendors microeconomics (SMEs), so that vendors can access the facilities and infrastructure for small and micro enterprises provided by the government, for instance through the provision of capital and strengthening of business management,

$>$ It should be efforts to bring visitors through the exhibitions or events that are expected to positively impact the marketing of goods traders if directed and nurtured and empowered, the impact on the national economy and a large enough area.

Recommendation: Some things to be done with regards to the empowerment of informal sectors:

- Goverment must provide a business location for informal sector traders to hold their

- Make policies in favor of the informal sector traders give policy benefit like party merchants, governments and other businesses.

- Empowerment of informal sector traders do specifically includes aspects of management and technical aspects

- Need further research on the influence of the informal sector traders to increase local revenue

\section{Reference}

Yustika, A. E. (2000). Industrialisasi Pinggiran, Pustaka Pelajar. Yogyakarta

Yustika, A. E. (2003). Industrialization,Urbanisation and Informal Sector.Perspektif Local Policy.Bayumas Malang.Indonesia

Boeke, J. H. (1978). Economics and Economic Policy of Dual Societies as Exemplied by Indonesia AMS Press. Jakarta

Lincolyn, Y. \& Egon, G. (1985). Naturalistic Inguiry.Santa Education Publication Beverly Hills

Manning, C. \& Tadjuddin E. N. (1996). Urbanisation,Unemployment, and nformal Sector in City.Jakarta.Yayasan Obor Indonesia

Manning C. (2000). Labour Market Adjusmant to Indonesia: s Economis Crosis; Contex Trend and Implications. Bulletin of Indonesian Economic Sudies, 36, 105-136 
Ramli, L. (1992) S. Infomal Sector Traders in City. Jakarta Penerbit In-Hill-Co

Simanjuntak, L. \& Wantonius, A. S. (2004). Analisys of Income Ciggarete Trader informal Sector in Medan City Development.Universitas Sumatera Utara. Medan.Indonesia 